\title{
Landmarks in Classical Literature
}


TO JEM 


\section{Landmarks in Classical Literature}

Philip Gaskell

Edinburgh University Press 
(C) Philip Gaskell, 1999

Transferred to digital print 2009

Edinburgh University Press Ltd

22 George Square, Edinburgh

Typeset in Futura and Sabon

by Bibliocraft Ltd, Dundee, and

Printed and bound in Great Britain by

CPI Antony Rowe, Chippenham and Eastbourne

A CIP record for this book is available from the British Library

ISBN 0748613625 (paperback)

The right of Philip Gaskell to be identified as author of this work has been asserted in accordance with the Copyright, Designs and Patents Act 1988 